\title{
DIAGNOSING VISCERAL LEISHMANIASIS AND HIVIAIDS CO-INFECTION: A CASE SERIES STUDY IN PERNAMBUCO, BRAZIL
}

Aracele Tenório de Almeida e CAVALCANTI(1), Zulma MEDEIROS(1,2), Fábio LOPES(2), Luiz Dias de ANDRADE(2), Valéria de Melo FERREIRA(3), Vera MAGALHÃES(4) \& Demócrito de Barros MIRANDA-FILHO(1)

\begin{abstract}
SUMMARY
HIV/AIDS-associated visceral leishmaniasis may display the characteristics of an aggressive disease or without specific symptoms at all, thus making diagnosis difficult. The present study describes the results of diagnostic tests applied to a series of suspected VL cases in HIV-infected/AIDS patients admitted in referral hospitals in Pernambuco, Brazil. From a total of 14 eligible patients with cytopenias and/or fever of an unknown etiology, and indication of bone marrow aspirate, 10 patients were selected for inclusion in the study. Diagnosis was confirmed by the following examinations: Leishmania detection in bone marrow aspirate, direct agglutination test, indirect immunofluorescence, rK39 dipstick test, polymerase chain reaction and latex agglutination test. Five out of the ten patients were diagnosed with co-infection. A positive direct agglutination test was recorded for all five co-infected patients, the Leishmania detection and latex agglutination tests were positive in four patients, the rK39 dipstick test in three, the indirect immunofluorescence in two and a positive polymerase chain reaction was recorded for one patient. This series of cases was the first to be conducted in Brazil using this set of tests in order to detect co-infection. However, no consensus has thus far been reached regarding the most appropriate examination for the screening and monitoring of this group of patients.
\end{abstract}

KEYWORDS: Visceral Leishmaniasis; HIV/AIDS; HIV/VL co-infection; Diagnostic tests.

\section{INTRODUCTION}

In HIV-infected patients, visceral leishmaniasis (VL) accelerates the onset of AIDS and the disease can progress rapidly into severe forms ${ }^{22,24}$. HIV-VL co-infection may appear clinically in its classical form or with very aggressive characteristics, sometimes non-specific and difficult to diagnose ${ }^{29}$.

The association between the diseases is recent and has an increasing number of cases in Brazil and worldwide - especially in the Mediterranean region of Europe ${ }^{15,18}$. In Brazil, a phenomenon of overlapping infections characterized by the ruralization of AIDS and urbanization of VL has been observed, which indicates the emergence of parasitic disease as an important infection opportunistic to HIVpatients ${ }^{11}$. However, there are very few reports from Brazil concerning co-infection ${ }^{6,10,17,25}$.

The present study describes the results of diagnostic tests applied to a series of suspected VL cases in HIV-infected/AIDS patients.

\section{PATIENTS AND METHODS}

HIV-infected/AIDS patients were included in the study after they were admitted to four public hospitals in Pernambuco, Brazil, between September 2008 and January 2010. The study included 18-year-old patients, who presented cytopenia (leucocyte count $<3,000 / \mathrm{mm}^{3}$, hemoglobin concentration $<10 \mathrm{~g} / \mathrm{dL}$, platelet count $<120,000 / \mathrm{mm}^{3}$ ) in at least two cell lines and/or fever $\left(>38^{\circ} \mathrm{C}\right)$ for more than eight days, with no defined etiology and indication of bone marrow aspirate from the doctor's assistant. The study was approved by the Research Ethics Committee at the Aggeu Magalhães Research Center - Fundação Oswaldo Cruz (CAAE 0121.0.095.000-08).

HIV diagnosis was confirmed by Western blot or indirect immunofluorescence ${ }^{7}$ and VL by identifying amastigotes in bone marrow aspirates and/or positive results in KAtex ${ }^{12}$, with good therapeutic responses.

Evidence for a favorable response to therapy (clinical remission) was considered when the patient was afebrile and when physical signs as well as laboratory abnormalities significantly improved after a complete course of treatment ${ }^{1}$.

The direct agglutination test (DAT) was used to detect antiLeishmania antibodies. A result was considered positive when $\geq 1 / 6,400^{21}$.

(1) Universidade de Pernambuco, Brazil.

(2) Fundação Oswaldo Cruz - FIOCRUZ (Centro de Pesquisa Aggeu Magalhães-Laboratório de Doenças Transmissíveis)

(3) Laboratório Central de Saúde Pública do estado de Pernambuco (Laboratório Dr. Milton Bezerra Sobral).

(4) Universidade Federal de Pernambuco (Hospital das Clínicas), Brazil.

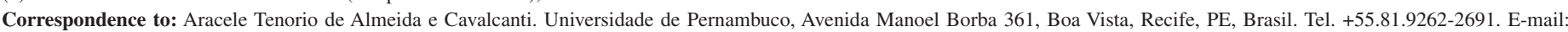
aracelecavalcanti@hotmail.com 
CAVALCANTI, A.T.A.; MEDEIROS, Z.; LOPES, F.; ANDRADE, L.D.; FERREIRA, V.M.; MAGALHAES, V. \& MIRANDA-FILHO, D.B. - Diagnosing visceral leishmaniasis and HIV/ AIDS co-infection: a case series study in Pernambuco, Brazil. Rev. Inst. Med. Trop. Sao Paulo, 54(1): 43-7, 2012.

The reaction to indirect immunofluorescence (IFA) was considered positive when fluorescence was observed in a dilution of $\geq 1 / 80^{18}$ and the rK39 dipstick test was considered positive when two lines were visualized on the strip 9 .

For the polymerase chain reaction in peripheral blood (PCR illustra TM tissue \& cells genomicPrep Mini Spin KIT), RV1 and RV2 primers were used ${ }^{15}$. DNA bands were separated by electrophoresis and visualized under a UV light, and photographed with the Kodak Gel Logic 100 Imaging System, using Kodak molecular imaging software 4.0.0. The latex agglutination test (Katex - Kalon Biological Ltd's, UK) was categorized as: positive +++ , and ++ , and + , and negative ${ }^{5}$.

\section{RESULTS}

Of the 14 eligible patients, two died before undergoing the bone marrow aspirate and two were excluded due to the existence of other diagnoses (tuberculosis and lymphoma). Nine patients were previously diagnosed as having AIDS and other case was diagnosed with AIDS during a screening of VL.

The mean age was 36.1 years $(27-44$ years/ \pm 5.8$)$. Five patients had attended school for 11 or more years and five owned a dog. All ten patients presented splenomegaly, weight loss and asthenia and one reported no fever.
Nine patients were male and came from the metropolitan region of Recife, of which eight were from the urban area and one from the rural area (Table 1)

Five co-infected cases were identified from amongst ten who were included in the study. Among the five cases of co-infection, there were two cases of VL (first episode) and three cases of relapse. Four patients tested positive for Leishmania in the bone marrow aspirate. A positive PCR was recorded for only one of these patients and nine patients obtained a positive DAT. Patient number 6 began a therapeutic test with amphotericin B prior to completing the examination for Leishmania in bone marrow aspirate, and tested negative, although the KAtex (++) and DAT $(1 / 12,800)$ were positive. A clinical improvement was observed with the therapeutic test: hematological counts were normalized and splenomegaly and fever reduced. Of the ten HIV-infected patients, nine (five with VL and four without VL) had a positive serologic test (DAT).

The mean age of the five co-infected patients was 37.2 (31-44 years \pm 6.0). Four were male, from the metropolitan region of Recife, and the only female patient was from the rural area. The female patient of this series was an agricultural worker, living in the agricultural zone of Pernambuco, and reported cases of VL at home (partner) and around the local neighborhood. Two of the male patients maintained sexual relations with other men and the female was in a stable relationship with her HIV-infected partner. None of the patients reported intravenous drug

Table 1

Results of specific tests in the ten HIV-infected/AIDS patients tested for visceral leishmaniasis during the period from September 2008 to January 2010 in four hospitals of Pernambuco, Brazil

\begin{tabular}{|c|c|c|c|c|c|c|c|c|c|}
\hline Patient & From & Sex & $\begin{array}{l}\text { Bone marrow } \\
\text { aspirate }\end{array}$ & DAT & rK39 & IFA & KAtex & PCR & $\begin{array}{l}\text { HIV/VL } \\
\text { co-infection }\end{array}$ \\
\hline 1 & $\begin{array}{l}\text { Recife } \\
\text { (Urban) }\end{array}$ & Male & negative & $\begin{array}{c}1 / 400 \\
\text { negative }\end{array}$ & negative & negative & negative & negative & negative \\
\hline 2 & $\begin{array}{c}\text { Cabo Sto } \\
\text { Agostinho (Urban) }\end{array}$ & Male & negative & $\begin{array}{l}\text { 1/6400 } \\
\text { positive }\end{array}$ & negative & negative & negative & negative & negative \\
\hline 3 & $\begin{array}{l}\text { Itamaracá } \\
\text { (Urban) }\end{array}$ & Male & negative & $\begin{array}{c}1 / 6400 \\
\text { positive }\end{array}$ & negative & negative & negative & negative & negative \\
\hline 4 & $\begin{array}{c}\text { Cabo Sto } \\
\text { Agostinho (Urban) }\end{array}$ & Male & negative & $\begin{array}{l}1 / 25600 \\
\text { positive }\end{array}$ & negative & negative & negative & negative & negative \\
\hline 5 & $\begin{array}{l}\text { Moreno } \\
\text { (Urban) }\end{array}$ & Male & negative & $\begin{array}{l}>1 / 51200 \\
\text { positive }\end{array}$ & negative & negative & negative & negative & negative \\
\hline 6 & $\begin{array}{l}\text { Recife } \\
\text { (Urban) }\end{array}$ & Male & negative & $\begin{array}{l}1 / 12800 \\
\text { positive }\end{array}$ & negative & negative & $\begin{array}{c}++ \\
\text { positive }\end{array}$ & negative & $1^{\text {st }}$ episode \\
\hline 7 & $\begin{array}{l}\text { Igarassu } \\
\text { (Urban) }\end{array}$ & Male & positive & $\begin{array}{c}>1 / 51200 \\
\text { positive }\end{array}$ & negative & negative & $\begin{array}{c}++ \\
\text { positive }\end{array}$ & negative & $1^{\text {st }}$ episode \\
\hline 8 & $\begin{array}{l}\text { Recife } \\
\text { (Urban) }\end{array}$ & Male & positive & $\begin{array}{l}>1 / 51200 \\
\text { positive }\end{array}$ & positive & negative & NM* & negative & $\begin{array}{c}\text { Relapse } \\
\left(2^{\text {nd }} \text { episode }\right)\end{array}$ \\
\hline 9 & $\begin{array}{l}\text { Glória de Goitá } \\
\text { (Urban) }\end{array}$ & Female & positive & $\begin{array}{l}1 / 1638400 \\
\text { positive }\end{array}$ & positive & $\begin{array}{c}1 / 80 \\
\text { positive }\end{array}$ & $\begin{array}{c}+++ \\
\text { positive }\end{array}$ & negative & $\begin{array}{c}\text { Relapse } \\
\left(2^{\text {nd }} \text { episode }\right)\end{array}$ \\
\hline 10 & $\begin{array}{l}\text { Igarassu } \\
\text { (rural) }\end{array}$ & Male & positive & $\begin{array}{l}1 / 25600 \\
\text { positive }\end{array}$ & positive & $\begin{array}{c}1 / 80 \\
\text { positive }\end{array}$ & $\begin{array}{c}+++ \\
\text { positive }\end{array}$ & positive & $\begin{array}{c}\text { Relapse } \\
\text { (3 } 3^{\text {rd }} \text { episode) }\end{array}$ \\
\hline
\end{tabular}

$\mathrm{NM}^{*}$ : Examination not made. 


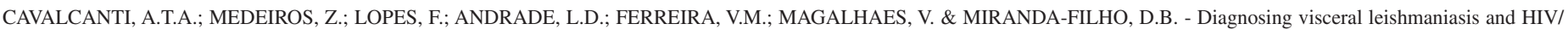
AIDS co-infection: a case series study in Pernambuco, Brazil. Rev. Inst. Med. Trop. Sao Paulo, 54(1): 43-7, 2012.

use. Two of these patients had attended school for more than 11 years and also owned dogs.

A positive DAT was recorded in all co-infected patients $(1 / 12,800$ $1 / 1,638,400)$. Four patients presented a positive KAtex test $(++/+++)$, and one did not perform the examination. Three patients recorded a positive rK39 dipstick test; two a positive IFA (1/80) and one patient presented a positive PCR (Table 1).

The mean CD4 count was 208 cells $/ \mathrm{mm}^{3}$ (56-399/ \pm 153$)$. Four patients were taking antiretrovirals (ART) and one was diagnosed with VL concomitantly with AIDS. The five patients diagnosed as co-infected were treated with amphotericin B. Three of the five cases diagnosed in the study reported previous episodes of co-infection, two of them relapsed in less than one year after treatment and did not receive prophylaxis, the other relapsed two years after discontinuation of prophylaxis with amphotericin B.

\section{DISCUSSION}

Five co-infected cases were identified from amongst ten who presented clinical indications of bone marrow aspirate, signs and symptoms compatible with classical forms of VL. The symptoms presented by the co-infected patients in this series may occur in other situations associated with AIDS, which can hinder or delay a clinical suspicion of $\mathrm{VL}^{10,22}$.

All patients had splenomegaly. Febrile splenomegaly and cytopenia in HIV-infected patients may also be observed in tuberculosis ${ }^{26}$, histoplasmosis $^{8}$ and lymphoma ${ }^{23}$. Cytopenias are frequent during the course of HIV infection and may result from several mechanisms ${ }^{24}$. In addition, is important to be alert for possible situations of co-infection where manifestations of VL are atypically presented ${ }^{28}$.

In this series, one of the five co-infected patients was diagnosed with VL concomitantly with AIDS. Visceral leishmaniasis may be the first infection related in $13 \%$ up to $47 \%$ of HIV-infected patients ${ }^{22,24}$. It is important to make an early diagnosis and monitor the development of leishmaniasis in HIV-infected patients, since these cases are less responsive to treatment and have higher fatality rates ${ }^{30}$.

All patients with previous episodes of VL had taken ART. In 2008, TER HORST, et $a .^{32}$, reported a reduction in the occurrence of new episodes with the use of ART. MIRA et al. ${ }^{19}$, however, concluded that if the patients had a high viral load and a low immune response, ART proved ineffective in preventing new episodes of the disease.

Microscopic observation of bone marrow aspirate is very specific (100\%), but sensitivity has been reported between $67 \%$ and $94 \% 9,24$. Several reasons have been cited for the limited sensitivity: a low number of Leishmania-infected cells as a consequence of pancytopenia; a hemodiluted sample due to inadequate collection or a low parasite load when the patient has already started therapy ${ }^{20,30}$. Patient six tested negative for Leishmania, but presented positive results with DAT and KAtex. This case was considered co-infection and showed a good therapeutic response.

Urinary antigen detection (KAtex test) was able to positively diagnose all cases of infection even after initiating amphotericin B. However, it has been reported that antigenuria becomes negative after successful chemotherapy, suggesting that KAtex may be a useful tool for monitoring the efficacy of the treatment ${ }^{2}$. In another two studies of co-infected patients in Spain, KAtex had a sensitivity of $85.7 \%$ and $100 \%$, respectively, when the parasite load was high ${ }^{27,34}$. ATTAR et al., ${ }^{5}$ reported the potential use of this test to diagnose active infection, although the need still exists for additional studies in order to provide a better definition of the role of KAtex, both in investigating the infection and during post-therapy follow-up. The present report of the use of KAtex in co-infected patients is the first publication on the Brazilian population. Whether the test is applicable to detecting asymptomatic or subclinical populations has still not been sufficiently clarified ${ }^{5,13,27}$.

The rK39 dipstick test confirmed the myelogram in all cases of recurrence, and no false-positive results were observed. In a study by SUNDAR et al. ${ }^{31}$, in India, the rK39 dipstick format has proved $100 \%$ sensitive and $98 \%$ specific when compared to splenic aspirates. Another validation study, conducted in a tertiary care hospital in southeastern Nepal, compared DAT with the rK39 dipstick test on 184 patients with a clinical suspicion of VL, and found a sensitivity of $97 \%$ and a specificity of $71 \%$ for the rK39 dipstick test ${ }^{9}$. The ease of use of the rK39 dipstick test and its low cost enable early diagnosis of VL in decentralized settings thereby improves access to early life-saving treatment ${ }^{33}$.

ASSIS et al. ${ }^{4}$, reporting in VL sensitivities and specificities of the DAT were $90 \%$ and $96 \%$, respectively. The authors concluded that DAT constituted a useful test and can replace IFAT as the routine diagnostic test used by the Brazilian Leishmaniasis Control Program. There is no consensus regarding the ideal cutoff point for co-infected patients. A positive DAT was recorded for all co-infected patients, but four out of the five patients not considered co-infected with VL also tested positive. The lowest titer amongst co-infected patients was $1 / 12,800$ (patient 7 ) and the highest was $1 / 1,638,400$ (patient 10). Two of the patients considered without VL had borderline titers $(1 / 6,400)$ and the other two obtained high titers for DAT $(1 / 25,600$ and $1 / \geq 51,200)$. One of them was diagnosed with a liver abscess and the other a pulmonary abscess. DAT, despite being one of the cheapest, simplest and most sensitive for diagnosing $\mathrm{VL}^{14}$, does not differentiate between past and recent infections ${ }^{35}$. The DAT test was not a diagnost criterion for co-infection study. This finding may be explained by a high prevalence of VL in the area. Due to the low sensitivity of bone marrow aspirate $(67-94 \%),{ }^{9,24}$ it is possible that patients with positive serology and negative aspirate actually had VL. The use of KAtex can, however, increase the sensitivity for the diagnosis of active disease $\mathrm{e}^{12,13}$.

Regarding serologic findings in this study, the functional impairment of cell-mediated immunity due to HIV infection may result in the absence of an antibody response to Leishmania infection, even when that is parasitemia. This impairment of the immune system may explain the higher frequency of false-negative antibody tests results in co-infected patients ${ }^{29}$. CHAPPUIS et al., ${ }^{9}$ suggest that patients who test positive with rK39 dipstick test or present elevated DAT titers, with a history of leishmaniasis, should be submitted to a Leishmania test by bone marrow or spleen aspirate in order to investigate co-infection.

No significant anti-Leishmania antibody titers were detected by immunofluorescence, and only two of the five cases tested positive. The 
CAVALCANTI, A.T.A.; MEDEIROS, Z.; LOPES, F.; ANDRADE, L.D.; FERREIRA, V.M.; MAGALHAES, V. \& MIRANDA-FILHO, D.B. - Diagnosing visceral leishmaniasis and HIV/ AIDS co-infection: a case series study in Pernambuco, Brazil. Rev. Inst. Med. Trop. Sao Paulo, 54(1): 43-7, 2012.

results of the present study are similar to studies that have described low titers for IFA in diagnosing co-infections ${ }^{24,29}$. The three cases with a new episode of co-infection presented positive results for rK39 dipstick test as well as DAT.

The PCR used was positive in only one of the five patients. The technique and the primers used in the PCR of this series are available within the leishmaniasis service in Pernambuco, although, there are no studies that validate them for co-infected HIV patients. A Brazilian study in $2006{ }^{11}$ using the same primers for PCR in the total blood of dogs, encountered a low sensitivity in this method and suggested the possibility of treating the low parasite load in the blood. The method used for DNA extraction, however, can have influenced the sensitivity and specificity of the PCR technique ${ }^{3}$.

This is the first study conducted in Brazil to investigate HIV-VL co-infection that describes the results of a set of diagnostic tools (parasitological, serological, molecular and urinary antigen detection). Only 14 patients were eligible for the study in more than one year. This low number of patients may be explained by the inclusion criteria based on the indication of bone marrow aspirate from the doctor's assistant.

This series has included only five patients with co-infection and it is difficult therefore to analyze the results of the different diagnostic tests. In addition, there were cases of relapse, making even more difficult to reach reliable conclusions. Despite the small size of the sample, this article is a valuable addition to the limited literature on a topic that is of growing importance, both in Brazil and in other VL-endemic areas of the world.

From the clinical symptoms of the suspected or confirmed patients it was possible to observe that there are still difficulties in screening and diagnosing this particular group of patients. Thus, it may be perceived that there are limitations in these diagnostic methods and further studies may indicate which examinations are most appropriate for diagnosing and monitoring patients with HIV-VL co-infection.

\section{RESUMO}

\section{Diagnosticando co-infecção leishmaniose visceral e HIV/AIDS: uma série de casos em Pernambuco, Brasil.}

A associação da leishmaniose visceral com o HIV/AIDS pode se manifestar com características de doença agressiva ou sem sintomas específicos, dificultando o diagnóstico. Este artigo descreve o resultado de testes diagnósticos aplicados a uma série de casos suspeitos de leishmaniose visceral em pacientes com HIV/AIDS internados em hospitais de referência de Pernambuco, Brasil. De 14 pacientes elegíveis com citopenias e/ou febre de etiologia indefinida, com indicações de mielograma, foram incluídos dez. Para o diagnóstico, foram empregados os seguintes exames: pesquisa de Leishmania em aspirado de medula óssea, DAT, IFI, rK39, PCR e a KAtex. Cinco dos dez pacientes foram diagnosticados com co-infecção. Entre os cinco co-infectados, o DAT foi positivo em todos, a pesquisa de Leishmania foi positiva em quatro, assim como o KAtex, o rK39 em três, a IFI em dois e a PCR positiva em apenas um. Esta série de casos foi a primeira realizada no Brasil utilizando esse conjunto de exames para detecção de co-infecção, no entanto, ainda não há consenso quanto aos exames mais adequados a serem aplicados para screening e acompanhamento desse grupo de pacientes.

\section{ACKNOWLEDGEMENTS}

Funding: This work was supported by grant APQ-1284-4.01/08 from the FACEPE (Foundation for Science and Technology of the State of Pernambuco) and PIBIC/CNPq (National Counsel of Technological and Scientific Development, Institutional Program for Scientific Initiation Scholarships), proposal contract No.: 109169/2009-3.

\section{REFERENCES}

1. Alexandrino-de-Oliveira P, Santos-Oliveira JR, Dorval ME, Da-Costa FC, Pereira GR, da Cunha RV, et al. HIV/AIDS-associated visceral leishmaniasis in patients from an endemic area in Central-west Brazil. Mem Inst Oswaldo Cruz. 2010;105:692-7.

2. Alvar J, Aparicio P, Aseffa A, Den Boer M, Cañavate C, Dedet JP, et al. The relationship between leishmaniasis and AIDS: the second 10 years. Clin Microbiol Rev. 2008;21:334-59.

3. Alvar J, Cañavate C, Molina R, Moreno J, Nieto J. Canine leishmaniasis. Adv Parasitol. 2004;57:1-88

4. Assis TS, Braga AS, Pedras MJ, Oliveira E, Barral A, de Siqueira IC, et al. Multicentric prospective evaluation of rk39 rapid test and direct agglutination test for the diagnosis of visceral leishmaniasis in Brazil. Trans R Soc Trop Med Hyg. 2011;105:81-5.

5. Attar ZJ, Chance ML, El-Safi S, Carney J, Azazy A, El-Hadi M, et al. Latex agglutination test for the detection of urinary antigens in visceral leishmaniasis. Acta Trop. 2001;78:11-6.

6. Carranza-Tamayo CO, Assis TSM, Neri ATB, Cupolillo E, Rabello A, Romero GAS. Prevalence of Leishmania infection in adult HIV/AIDS patients treated in a tertiarylevel care center in Brasilia, Federal District, Brazil. Trans R Soc Trop Med Hyg. 2009;103:743-8.

7. Centers for Disease Control. 1993 revised classification system for HIV infection and expanded surveillance case definition for AIDS among adolescents and adults. MMWR Recomm Rep. 1992;41(RR-17):1-19.

8. Chang MR, Taira CL, Paniago AMM, Taira DL, Cunha RV, Wanke B. Study of 30 cases of histoplasmosis observed in the Mato Grosso do Sul State, Brazil. Rev Inst Med Trop Sao Paulo. 2007;49:37-9.

9. Chappuis F, Rijal S, Singh R, Acharya P, Karki BMS, Das ML, et al. Prospective evaluation and comparison of the direct agglutination test and an rK39-antigen-based dipstick test for the diagnosis of suspected kala-azar in Nepal. Trop Med Int Health. 2003;8:277-85.

10. Daher EF, Fonseca PP, Gerhard ES, Silva Leitão TMJ, Silva Júnior GB. Clinical and epidemiological features of visceral leishmaniasis and co-infection in 15 patients from Brazil. J Parasitol. 2009;95:652-5.

11. Dantas-Torres F, Brandão-Filho SP. Expansão geográfica da leishmaniose visceral no Estado de Pernambuco. Rev Soc Bras Med Trop. 2006;39:352-6.

12. Ghatei MA, Hatam GR, Hossini MH, Sarkari B. Performance of latex agglutination test (KAtex) in diagnosis of visceral leishmaniasis in Iran. Iran J Immunol. 2009;6:202-7.

13. Gavgani AM, Vatan SK, Ghazanchaei A. KAtex antigen-detection test as a diagnostic tool for latent visceral leishmaniasis cases. Afr J Biotechnol. 2008;7:852-9.

14. Hailu A, Berhe N. The performance of direct agglutination tests (DAT) in the diagnosis of visceral leishmaniasis among Ethiopian patients with HIV co-infection. Ann Trop Med Parasitol. 2002;96:25-30.

15. Le Fichoux Y, Quaranta JF, Aufeuvre JP, Lelievre A, Marty P, Suffia I, et al. Occurrence of Leishmania infantum parasitemia in asymptomatic blood donors living in an area of endemicity in southern France. J Clin Microbiol. 1999;37:1953-7. 
CAVALCANTI, A.T.A.; MEDEIROS, Z.; LOPES, F.; ANDRADE, L.D.; FERREIRA, V.M.; MAGALHAES, V. \& MIRANDA-FILHO, D.B. - Diagnosing visceral leishmaniasis and HIV/ AIDS co-infection: a case series study in Pernambuco, Brazil. Rev. Inst. Med. Trop. Sao Paulo, 54(1): 43-7, 2012.

16. Lyons S, Veeken H, Long J. Visceral leishmaniasis and HIV in Tigray, Ethiopia. Trop Med Int Health. 2003;8:733-9.

17. Maia-Elkhoury ANS, Carmo EH, Sousa-Gomes ML, Mota, E. Análise dos registros de leishmaniose visceral pelo método de captura-recaptura. Rev Saude Pública. 2007;41:931-7.

18. Marques N, Cabral S, Sá R, Coelho F, Oliveira J, Saraiva da Cunha JG, et al Leishmaniose visceral e infecção por vírus da imunodeficiência humana na era da terapêutica anti-retrovírica de alta eficácia. Acta Med Port. 2007;20:291-8.

19. Mira JA, Corzo JE, Rivero A, Macías J, De León FL, Torre-Cisneros J, et al. Frequency of visceral leishmaniasis relapses in human immunodeficiency virus-infected patients receiving highly active antiretroviral therapy. Am J Trop Med Hyg. 2004;70:298-301.

20. Molina I, Falcó V, Crespo M, Riera C, Ribera E, Curran A, et al. Efficacy of liposomal amphotericin B for secondary prophylaxis of visceral leishmaniasis in HIV-infected patients. J Antimicrob Chemother. 2007;60:837-42.

21. Osman OF, Oskam L, Zijlstra EE, Kroon NC, Schoone GJ, Khalil ET, et al. Evaluation of PCR for diagnosis of visceral leishmaniasis. J Clin Microbiol. 1997;35:2454-7.

22. Pasquau F, Ena J, Sanchez R, Cuadrado JM, Amador C, Flores J, et al. Leishmaniasis as an opportunistic infection in HIV-infected patients: determinants of relapse and mortality in a collaborative study of 228 episodes in a Mediterreanean region. Euro J Clin Microbiol Infect Dis. 2005;24:411-8.

23. Pastore RD, Chadburn A, Kripas C, Schattner EJ. Novel association of haemophagocytic syndrome with Kaposi's sarcoma-associated herpesvirus-related primary effusion lymphoma, Br J Haematol. 2000;111:1112-5.

24. Pintado V, López-Vélez R. HIV-associated visceral leishmaniasis. Clin Microbiol Infect. 2001;7:291-300.

25. Rabello A, Orsini M, Disch J. Leishmania/HIV co-infection in Brazil: an appraisal. Ann Trop Med Parasitol. 2003;97(Suppl 1):17-28.

26. Reyes Corcho A, Díaz Jidy M, Pérez Rodriguez A, Bouza Jiménez Y, Bouza Jiménez Y. Factores asociados con la presnecia de tuberculosis en pacientes con el syndrome de inmunodeficiencia adquirida en Cuba. Rev Panam Salud Publica. 2004;15: 341-7.
27. Riera C, Fisa R, Lopez P, Ribera E, Carrió J, Falcó V, et al. Evaluation of a latex agglutination test (KAtex) for detection of Leishmania antigen in urine of patients with HIV-Leishmania co-infection: value in diagnosis and post-treatment follow up. Eur J Clin Microbiol Infect Dis. 2004;23:899-904.

28. Roselino AM, Chociay MF, Costa RS, Machado AA, Figueiredo JFC. L. (L.) chagasi in AIDS and visceral leishmaniasis (kala-azar) co-infection. Rev Inst Med Trop Sao Paulo. 2008;50:251-4

29. Sinha PK, Pandey K, Bhattacharya SK. Diagnosis \& management of leishmania/ HIV co-infection. Indian J Med Res. 2005;121:407-14.

30. Sundar S, Chakravarty J, Agarwal D, Rai M, Murray HW. Single-dose liposomal amphotericin B for visceral leishmaniasis in India. N Engl J Med. 2010;362:504-12.

31. Sundar S, Reed SG, Singh VP, Kumar PC, Murray HW. Rapid accurate field diagnosis of Indian visceral leishmaniasis. Lancet. 1998;351:563-5.

32. Ter Horst R, Collin SM, Ritmeíjer K, Bogale A, Davidson RN. Concordant HIV infection and visceral leishmaniasis in Ethiopia: the influence of antiretroviral treatment and other factors on outcome. Clin Infect Dis. 2008;46:1702-9.

33. Ter Horst R, Tefera T, Assefa G, Ebrahim AZ, Davidson RN, Ritmeijer K. Field evaluation of rK39 test and direct agglutination test for diagnosis of viscera leishmaniasis in a population with high prevalence of human immunodeficiency virus in Ethiopia. Am J Trop Med Hyg. 2009;80:929-34.

34. Vilaplana C, Blanco S, Domínguez J, Giménez M, Ausina V, Muñoz C. Noninvasive method for diagnosis of visceral leishmaniasis by a latex agglutination test for detection of antigens in urine samples. J Clin Microbiol. 2004;42:1853-4.

35. Zijlstra EE, Ali MS, El-Hassan AM, El-Toum IA, Satti M, Ghalib HW, et al. Kalaazar: a comparative study of parasitological methods and the direct agglutination test in diagnosis. Trans R Soc Trop Med Hyg. 1992;86:505-7.

Received: 24 July 2011

Accepted: 14 December 2011 